\title{
On the heaviness of feathers, or what has culture got to do with the failure to establish an organic poultry production business in contemporary Serbia?*
}

\begin{abstract}
This case study starts from the thesis that the analysis of life histories, coupled by observation of actual behaviour, can contribute to a more nuanced understanding of the ways in which overarching categories like "socio-economic cultures" actually function in the local and national settings. It is based on in-depth interviews with a former top manager in the agro-veterinary section of a Serbian export-import firm. The informant presents the reasons that have influenced him to leave his job and attempt to establish an organic agro-business, offers a personal view of political and cultural factors that have caused the decline of Yugoslav and Serbian economies, and explains how these factors have influenced his business and family survival strategies, among which exploitation of family work and instrumentalisation of kinship and neighbourhood networks were most prominent. The case study thus reveals the actual "cultural resources" that the informant was ready to turn to in order to sustain his entrepreneurial efforts. Next, the case study suggests that "narrow" professional cultures, like managerial or entrepreneurial cultures, can have more impact on individual behaviour than "broader" national or regional cultures. In that sense, when the functioning of national "socio-economic culture(s)" is properly contextualized, then it has to be seen as neither the only, nor the principal factor that can explain observable behaviour, particularly in rapidly changing political, economic, institutional, and legal settings, characterised by lingering state capitalism, conquering predatory capital accumulation, semi-functional legal system, agricultural policy breakdown, and rampant corruption.
\end{abstract}

Key words: Socio-economic culture, managerial culture, entrepreneurial culture, culturalism, institutionalism, political transition

\footnotetext{
* Текст је резултат учешћа у научноистраживачком пројекту бр. 147035 који
} финансира МНЗЖС РС.

Етноантрополошки проблеми н.с. год. 1. св. 1 (2006) 
One thing is certain, however, and that is that the future of those states now emerging from the debris of war and their place in a wider European economy will be shaped in significant measure by the changing nature and role of agriculture.

John B. Allcock, Explaining Yugoslavia, 2000, p. 144

The precondition for the development of the agro-sector in Serbia lies in the resolution of problems of institutional nature, the transformation of legal-economical regulations, the decrease in administrative interference, and, in the first place, in the establishment of a functioning market of capital. Everything else is pure demagogy.

G17 Bulletin, no. 7, 2000, p. 5

This paper ${ }^{*}$ is based on a series of in-depth interviews with Milutin ${ }^{1}$, a former top manager in the agro-veterinary section of what used to be a large Serbian export-import firm. Observation of the functioning of his family business, and informal talks with his business partners provided additional information. In the interviews, Milutin discusses the reasons that have influenced him to leave his once highly esteemed managerial job, struggle as an individual agricultural producer for almost a decade, attempt to establish an organic poultry production business of his own, and finally return to his original profession of being a manager in agribusiness. Examined are also the numerous external factors that slowed down or completely blocked his entrepreneurial efforts. On the way, the organising principles of his business venture are revealed, together with the survival strategies to which he and his family had to turn to during a truly difficult period. In that sense, what follows can be seen as an effort to untangle and systematise a complex web that intertwined selfpresentations of the interviewee as he balanced between the roles of manager, small scale agricultural producer and entrepreneur, his caustic explanation of the logic of decline of Yugoslav and Serbian agriculture and economy in general upon which he based his business and subsistence strategies, various

* The present text is a shortened and adapted version of the Serbian agricultural case study in the frame of the project "After the Accession ... The Socio-Economic Culture of Eastern Europe in the Enlarged Union: An Asset or a Liability?", headed by Dr. Janos Matyas Kovacs in the frame of the Institute for Human Sciences (IWM, Vienna), and financed by the Austrian Ministry of Foreign Affairs. A shorter version of this paper was published in Hungarian translation (Naumović 2005). I am indebted to Dr. Kovacs for his helpful editing suggestions. My most profound gratitude is reserved for Milutin and his family. Without their openness, trust, patience and good will this study would have been unthinkable.

${ }^{1}$ The names and initials that appear in this text are all changed.

Етноантрополошки проблеми н.с. год. 1. св. 1 (2006) 
cultural factors that functioned both as resources for, and determinants of his behaviour, as well as institutional and legal frames that were restricting or shaping in other ways his activities. ${ }^{2}$

\section{The good old, bad old days, or on doing business during the beginning of the end}

Milutin was born in 1957 into a family living in a small house in an old, village-like quarter of Novi Beograd, the grand socialist dormitory built after WWII on dried-up swamps between the rivers Sava and Danube. His parents, who both moved from their villages to Belgrade, worked as technicians in a large agricultural machine factory. He had a troubled but colourful childhood, and still savours the days when his father took him to the river on fishing hikes. After his parents divorced, he and his sister were supported by their mother from a single salary, moving from one rented flat to the other. As he put it, during these years they had everything, but not much of it. As a very good pupil, he had a wide range of opportunities for study, but his mind was set when he learned that "there was a department where one could learn about fish and fishing". With time, his interests widened, but the animal world remained a priority. He graduated from the Belgrade Faculty of Agriculture in 1983, obtaining the title of engineer of cattle-breeding.

Being an exceptional student who could speak two foreign languages fluently, he was offered a job in the agro-veterinary department of a leading Serbian chemical export-import company immediately upon graduation. He remained in the company from 1983 to 1992, rising to the post of leading manager of the department, with a yearly turnover exceeding ten million DM. Among other assignments during that period, he was responsible for the intensive business cooperation with the agro-vet division of one of the greatest German chemical concerns at that time. While in the company, Milutin acquired a large and versatile professional experience, and an in-depth knowledge of Western European, and in particular German business milieus.

\footnotetext{
${ }^{2}$ For an inspiring and instructive review of crucial topics in the study of post-socialist rural transition, see Swain 2000. For a collective sociological portrait of entrepreneurs in Serbia, see Bolčić 1997-98, 3-35. The difference between managers and entrepreneurs is taken here to have practical and theoretical implications. Contrary to managers, who operate under conditions and with resources known and controllable in advance, entrepreneurship is here defined, following Sahlman and Stevenson as a "way of managing that involves pursuing opportunity without regard to the resources currently controlled. Entrepreneurs identify opportunities, assemble required resources, implement a practical action plan, and harvest the reward in a timely, flexible way" (cited after: Verheul, et al., 2001, 4).
} 
We were orientated mostly towards the West... The West significantly influenced our profession... We did not represent a typically East European country because we started taking advantage of western know-how, genetics, technology, and mechanization in contrast to other Eastern countries....

He perfected his knowledge and skills during several business crash courses at top-ranking German institutions, basically covering professional knowhow, communication skills, marketing approaches, and language skills. There was also much to be learned about various European cuisines, wines, and restaurant culture in general, as well as about vital additional business skills, like drinking-and-not-getting-drunk while memorising important information, and taking care not to reveal professional secrets. ${ }^{3}$ He thus gained ease and self-confidence, and sharpened his business intuition. Opportunities to glimpse the other side of Western professionalism, or should one say socio-economic culture, also appeared. The "lessons" ranged from the simple, legally dubious but economically convenient practice of asking for "good bills" that could be cashed at the expense of the firm, all the way to complex strategies of tax evasion.

Serious cultural differences existed between us... For example, I also learned about corruption only after I started working for them (the German companies, S.N.). For the first time in my life, I heard from a manager: "Ask the waiter to give you a good bill". What is a "good bill"? If the bill is $450 \mathrm{DM}$, let the waiter write you a bill on the sum of 1,600 DM, said the manager. I was then 27 or 28 years old. This is how I bumped into corruption. My salary at that time was solid: 1,000 or $1,100 \mathrm{DM}$ per month. They had about 15,000 DM per month and still were cheating their companies regularly...

All these additional lessons make it possible to speculate that as a determinant of economic behaviour the professional culture(s) into which one is initiated during his/her career are at least as important, if not more so, than the national socio-economic culture into which one is socialized from early age. The self-perception of being a manager who can operate on an equal basis with his Western counterparts, based on extensive contacts with Western know-how, and the idealisation of his own professional milieu as a niche of orderliness, organization, and strict work ethic that equalled, if not surpassed Western standards, have never left our informant, even when they started bumping into "rough realities" during the nineties.

\footnotetext{
${ }^{3}$ The practical aspects of managerial culture(s), the actual "field" know-how and the conceptual schemes that go with it, are systematically neglected by the value-centered studies, much to the detriment of our understanding of the actual functioning of specific socio-economic cultures. A "proper" anthropology of managerial, entrepreneurial and business cultures in the region is therefore still in the making.
}

Етноантрополошки проблеми н.с. год. 1. св. 1 (2006) 
Apart from stressing the importance of professional culture(s), Milutin's case also points to the effects that particular individual experiences have on the perception and remembrance of specific historical periods. Thus, while he was very well aware of the rapid progression of the economic crisis at the time, he is not the only one to remember the eighties as the "golden years", during which, at least in the domain of agro-business, Yugoslav firms could attempt to deal with Western European ones on a more or less equal basis, and during which there were even opportunities for professional and economic growth. ${ }^{4}$

When I started to work the complete accumulation of the Agro-vet division amounted to 130,000 Dinars a year. In six years, that amount went up to more than 10 million DM. I intensely contributed to that result. ... Since I had the opportunity to take part in East European conferences between 1983 and 1992 I declare with responsibility that we were, at least from the point of view of animal production, the most developed country in that area of Eastern Europe (having in mind the USSR of that time, Poland, Czechoslovakia, Hungary, Romania, Bulgaria).... We were unapproachable and they were simply moving slowly, at least ten years behind our back... At that time, we had extensive export, in the first place of chicken, to the Middle East, the USSR, export of beef to Greece, Great Britain - the cost of Serbian beef in Thessaloniki was $40 \%$ higher than of beef from most other parts of the world because of its top quality... Yugoslavia had clear advantages, extremely large presentations at agricultural fairs, at regional consultations, annual symposia...

At that time, we still thought that we could catch up with Austria in two, three years. Such was the conception of the team I worked in. We were not only young and aggressive, we were successful as well....

From the economic point of view, the period between 1980 and 1990 represented a golden age when our currency was still partially convertible. Our economy was relatively functional at that period, at least as far as agriculture and agribusiness are concerned...Therefore I personally look upon that period as a positive one...

In the harsh times that were soon to follow, the rather specific cultural package of professional skills, knowledge and working habits that the informant acquired during "the golden age" paradoxically proved to be both an asset (in cases in which precise knowledge and well established professional routines and contacts were necessary) and a liability (when risk taking, improvisation, originality and intuition were needed).

\footnotetext{
${ }^{4}$ For a radically different, caustic view of the economic "logic" of Yugoslav socialism in its terminal phase, based on a detailed case study of one of the "prides" of Serbian and Yugoslav socialist economy, the giant metallurgical "kombinat" at Smederevo, see Palairet 1997. The discrepancy between the "golden age" and "decline" perspectives can also be seen as reflecting the often inversed fates of the export-import and production oriented firms in Serbia and Yugoslavia.
}

Етноантрополочки проблеми н.с. год. 1. св. 1 (2006) 


\section{Manager into peasant, or on the consequences of serbia's 'economy of destruction'}

In the early nineties, as the economic and political situation rapidly deteriorated, and the wars and sanctions blocked international cooperation and trade, Milutin's company all but collapsed. He decided to leave it, instead of waiting passively to be sent on a "prolonged vacation" with no salary, as was happening to other colleagues who, like him, lacked adequate political backing.

Economic sanctions against our country were imposed in $1992 \ldots$ That was very painful. When you wanted to trade with a foreign company you had to smuggle money in bags, to meet the people in Hungary... The situation of my institution rapidly worsened, it could not carry on business, the agricultural segment of my firm went on with some its activities, but the whole division of organic and inorganic chemistry, of tires and trade vehicles stopped working, while salaries dramatically decreased. At the beginning of October 1991 my salary was between 1,100 and 1,200, and the stimulation was up to 2,000 DM. It fell down by September 1992 to only 50 or $60 \mathrm{DM}$ per month, and continued to drop. My home savings melted away, practically disappeared. The spring of 1992 was extremely hard; business was almost completely interrupted... workers were sent to their homes on unpaid or "paid" vacations with 10 or 15 DM a month... That moment marked a turning point in the life of the whole society.

As production oriented companies targeting domestic markets had at least some chances of surviving, he accepted the offer to become the director of the poultry production branch of a well known "agro-kombinat" from Vojvodina. He thus had the opportunity to perfect his knowledge of the technology of a specific type of meat production. As the production facilities were scattered all over Serbia, including Kosovo, he learned the hard way about tremendous differences in professional knowledge, work ethic and ways of doing things in what was supposed to be a single economic, administrative and political entity. He found out the hard way that knowledge, determination and good will could hardly counter malignant general trends that were rapidly spreading in the society in general, and in the economic sector in particular. General loss of motivation resulting in poor work results, coupled with cynical large scale

\footnotetext{
${ }^{5}$ The best introduction to the complex problem of the interrelation of economic and political factors on the global and local levels, and of their at times paradoxical effects on the fate of the Yugoslav Federation was supplied by Woodward 1997, in particular in the first five chapters. For penetrating insights into the logic of politically induced economic decline of Serbia and Yugoslavia during the nineties see Lazić, ed., 1994. A contrastive assessment of factors that determine competitiveness of agricultural producers and food processing enterprises in Bulgaria is offered in Vladimirov 2003.
}

Етноантрополошки проблеми н.с. год. 1. св. 1 (2006) 
plundering strategies devised by politically protected individuals, soon ate up whole production units of the company. ${ }^{6}$

The new "businesspersons", which appeared after Milošević came to power, succeeded with bribes of 1,000 or 2,000 DM to obtain goods worth 200,000 or 300,000 DM, and even millions. The active stuff, the state owned capital was simply vanishing. ...The official leaders of production were big social firms, but we managed to survive owing to small, invisible farms, untouched by such siphoning strategies. They were... a strategic reserve. In that particular domain, looting and inflation were "helpless"...

Backed by some workers, Milutin tried to resist these tendencies, and even fight some of the perpetrators, only to learn that "friends from above" meant more than "support from below". After orchestrated campaigns of personal discrediting, several threats to his life, and desertion by many of those whose interests he was principally defending, Milutin decided that his family's and his own wellbeing meant more to him than what was clearly becoming a struggle against the windmills.

Disgusted and tired, Milutin decided to leave the big city, which for him had become "the symbol of corruption and moral decay", and make true his one time dream of living in his own house in a village by the river. He first bought a parcel of land, and tried rather unsuccessfully to set up a small corn production. He then persuaded his mother to sell her flat in the city, and they bought a small house with an additional stretch of land in a village in Srem, a historical region of Vojvodina. The house remains his mother's property, while both parcels of land and the objects built on them belong to him.

Having previously mastered the technology of egg and poultry meat production, Milutin decided to abandon working the land, and set up his own poultry production business. However, with no fresh capital, as the family savings were already depleted by the loss of fresh income and rampant inflation, and as the collapsing state saw no interest in crediting small scale producers, the venture came to be much more difficult than originally planned. He had to wok hard to adapt the old house, and build two new production objects largely by himself, with help coming in only from family members.

The years between 1992 and 2002 were truly very difficult... when I invest 10,000 DM, raise 2,000 chickens, sell them very successfully, get back the invested capital in Dinars, and try to change back that amount in the black market I find out that I can buy back $10,000 \mathrm{DM}$ at the very best, and usually less, although I spent 60 days on ra-

\footnotetext{
${ }^{6}$ For a general introduction to the depressing topic of corruption in Serbia, see Begović and Simić, eds., n.d.. Similar politically backed "rent-seeking and asset-scraping strategies" are analysed in the Bulgarian context in Tchalakov 2003, in particular pp. 3-4.
} 
ising the chicks, and sometimes additionally paid primary and manufacturing components, and 1 or 2 workers. No profit, or outright loss. It happened to many other producers as well. On the other hand, the black-marketers got back at least 15,000 DM for $10,000 \mathrm{DM}$ invested in petrol, and usually more than double. The consequences were that small-scale producers depending on small cycles somehow remained alive, while most of the bigger producers were completely ruined financially...

By the end of the nineties, after years of sweating and freezing round the clock, and not a single day of holiday, the results could hardly match the original intention and expectations. Instead of developing into a medium scale advanced farming production he dreamed of, his tireless efforts managed nothing else but to turn his whole family into a peasant subsistence production unit, selling eggs and poultry to neighbours, relatives, and local market customers, with relatively infrequent and unreliable larger commands as the only reward one could hope for.

How sustainable is a sustainable agriculture project in reformist Serbia, or why do (some) entrepreneurs fail in the transitional economy?

Great expectations were stirred again in the year 2000 by the "Belgrade October Revolution". ${ }^{7}$ Hopes were high, and so was enthusiasm. A new era was dawning, or so the people on the streets thought. Unfortunately, various political brands of democrats were soon busy quarrelling over who was the veritable reformer, and who should thus take on the "burden" of numerous "responsibilities", and with it all the spoils of unrestrained power. It became obvious that regimes can indeed be changed overnight, but not human characters, passions and weaknesses. However, undeniable progress was being made, at least initially, in a number of key sectors like macroeconomic reforms, monetary policy, bank restructuring, legal reform and diplomacy. ${ }^{8}$ Donations and credits started pouring in, though hardly reaching either promised or expected levels.

Believing that the long awaited moment to start a serious production had finally arrived, Milutin contacted in the beginning of 2002 his one time professional acquaintance and friend, the owner and general manager of a chain of agro-businesses from Germany, and arranged a professional meeting with

\footnotetext{
${ }^{7}$ For a well argued assessment of the state of Serbian economy that was inherited by the reformists from the previous regime, see Arandarenko 2000.

${ }^{8}$ On the debates focusing the importance of legal systems for economic development, see Perry 2002 : 282-307.
}

Етноантрополочки проблеми н.с. год. 1. св. 1 (2006) 
him on one of his contractor farms in Hungary. He was also approached by two friends (an unemployed precision mechanic and a taxi driver with extensive experience in the "grey economy", principally dealing with detergents and fruit juices) who were willing to join forces. His initiative could be interpreted as an attempt of economic take-off from the frugal level of subsistence production into the expected heights of entrepreneurship. However, it was also a brutal test of whether being a good manager in relatively stable socialist times was all that was needed for becoming a successful entrepreneur under the uncertainties of a transitional economy.

The deal was to set up a joint-venture agricultural firm in Serbia in the beginning of 2003, and start a domestic and export-oriented organic production of turkey meat, coupled by the import and sale of veterinary medicaments and chemicals. ${ }^{9}$ Also planned was the transfer to Serbia of a small-scale slaughterhouse and poultry meat processing facility from a contractor farm in Hungary. It was a well devised attempt to take advantage of a blank spot in the local production chain in order to secure a first-row position in a developing and potentially highly profitable business. However, due to a bureaucratic steeplechase that prolonged the registration of the firm for more than six months, and even more so to the tragic murder of the Serbian prime minister in the spring of 2003 and the resulting anti-mafia campaign that reoriented political and other priorities in Serbia, the 2003 legal term for agricultural import was missed, and the whole planned cycle had to be cancelled.

We made a specific agreement on how we should organize deficient production, i.e. a new program of organic-food production, which has not earlier been known nor introduced in our milieu. It would make possible the employment of cheap labour force, significantly cheaper than in the West. We have immediately engaged a professional legal representative and started to fill out many forms, more than 30. Additional proofs and certificates have also been submitted. Taxes have been paid... There were occasions when an ordinary court clerk, not even an archivist, sent us away from the window although his only job was to receive those documents and to see whether a money order and tax receipt are attached to the documents...I told them that we have a foreign partner, that we have knowledge, and a project of our own which could function well. ... It took us more than 6 months only to register our firm, although we practically made immediate payments, opened accounts, submitted evidences of our

\footnotetext{
${ }^{9}$ For the ideas and ideologies behind the project of sustainable agriculture see Bønneland et al. 2002, and van Brakel et al. 2002. Of particular interest for the understanding of sustainable agriculture and organic production in accession countries is Konečni, ed. 2003. For a description of the potential benefits of such developments in countries that have suffered the breakdown of industrialized agriculture and its extensification, in other words for the strategy of "turning agricultural backwardness into an advantage" see Nemes 2003/2004.
} 
professional education, of rented commercial premises, and of every demanded peace of paper. ...In the course of the 6-month period, I had to lie to the man who has been my friend for 20 years.... I had to find excuses that would sound credible. I had to explain to him that the state has changed, that Federal Republic of Yugoslavia does not exist any longer, that our state is Serbia and Montenegro, that the laws are being changed, that our Prime Minister has been killed, that extraordinary measures have been taken...

It was hardly surprising that the ever more visible mixture of bureaucratic paralysis, institutional inefficiency, legal insufficiency, large scale corruption related to the process of privatisation, and of renewed political instability in Serbia, made the German partner (and German banks and insurance companies as well) hesitant. That meant that the potential financial and technological engine of the venture became detached even before the actual journey started, and that the train from that moment onwards had to run on the feeble thrust supplied by the previously existing family business. What seemed as a viable project started to collapse like a dried-up sand castle before Milutin's very eyes. Disappointment and bitterness filled the void that was left after enthusiasm and great expectations faded away:

The present-day ruling circles are ashamed of confessing their incapability. When someone advises his peasants not to produce wheat ... what can it mean? It is some kind of indifference. Reality is very rough, very brutal, and completely different from what it was 20 years ago. On the other side, legal regulations and the style of administrative thinking did not significantly change; administration did not largely change, it remained the same. On the one hand, you have the alleged paradise in legislation, and on the other real hell on Earth. The much publicized instruction of people to cultivate soybeans instead of wheat requires modern mechanization, a series of benefits like tax reduction or exemption from tax, even considerable sums of money in advance, favourable credits... Promises are not kept, the needed frames do not exist, but people are advised to produce industry plants instead of wheat. It makes no difference to them whether farmers will be ruined ... They apparently think that we can import everything we lack. Are they aware of the fact that our population could be hungry tomorrow?...

In our country, things have no chances of getting better while the best-developed field is fog selling. Because you are engaged in production, you end up being a fool.

Етноантрополошки проблеми н.с. год. 1. св. 1 (2006) 


\section{The secrets of (some) transitional entrepreneurs, or on the organisation of the family business ${ }^{10}$}

The heart of the business venture, the family production unit, consisted of Milutin, his mother, his wife, his two daughters, and a cousin, a retired army officer who came to live on the estate in the year 2000. The family subsistence strategy was the only possible mechanism of preserving the production in the harsh years characterised by sanctions and hyperinflation, as a permanent hired workforce and related monetary loss would have suffocated it economically. ${ }^{11}$ For almost a decade, the venture remained legally in the grey zone.

As was stated above, early in 2003 the family venture turned into a short-lived organic agro-business, which functioned legally till the end of 2004. It was registered as a four partner mixed (foreign and domestic) shareholder society with limited responsibility. Apart from Milutin, the local company members were S.S. and Z.Z. (both of whom left the company before the end of 2004), while M.M. represented the foreign partner and owner of $49 \%$ of the company's rather symbolic founding capital. While the operating plan was precisely laid down on a joint meeting of its founding members in Hungary, it soon became clear that the future of the joint venture would depend mostly on the political, economic and legal outcomes of the political struggles raging in Serbia at that time, as well as on the entrepreneurial talents of the Serbian partners.

Actual working tasks were more or less evenly distributed among the family members, but there were specialised and generalised tasks. The informant was constantly switching between the roles of entrepreneur, manager and principal work force. It was his exclusive task to prepare the poultry food, administer medicines when needed, slaughter fully grown up chicks and turkeys, and organise the veterinary control of the meat, but he also participated in all other daily activities. Milutin was aided by all members of the family, as

${ }^{10}$ The full version of this case study incorporates detailed descriptions of the facilities and production cycles, but they had to be omitted here due to restricted space. For a clarification of the general trends in Serbian agriculture and agribusinesse see: Bogdanov 2002, and in particular the very detailed Chapter 11. Agriculture, in: Federal Republic of Yugoslavia. Breaking with the Past: The Path to Stability and Growth. Volume I: The Economic, Social and Institutional Reform Agenda (2001). A detailed vision of the needed structural changes in Sebian agriculture is presented in Strategija poljoprivrede Srbije, the official policy document prepared by the Ministry of Agriculture in 2004 and approved by the Serbian Parliament in 2005. For a concise, but devastating critique of the consequences of Milošević's economy in the domain of agriculture see Palairet 2001, in particular 6-7. For a broader historical perspective see: "Economic modernisation: the agrarian economy" in Allcock 2000 : 100-144.

${ }^{11}$ For various survival strategies in post-socialist transition see: Babović and Cvejić 2002; Kuczi 1997-98; or Chevalier 2001.

Етноантрополошки проблеми н.с. год. 1. св. 1 (2006) 
well as by S.S. in the everyday tasks like feeding and cleansing, as well as peak activities like preparing and packing of the meat, and was eventually replaced by them if some of his tasks overlapped. Interestingly, it was S.S.'s exclusive duty to find and contract larger customers and arrange the deliveries to them, and to organise the transportation of meat to other smaller customers. S.S. was relying on the extensive networks built up during the time when he was engaged by his "grey zone" detergent and fruit juice businesses, and on the acquaintances and contacts that he developed as a taxi driver. ${ }^{12}$ Before she found a job, Milutin's wife was also engaged as a saleswoman on the rented market stands. Depending on their individual obligations, family members also carried and distributed smaller packs of meat to individual customers, primarily friends, neighbours, or distant relatives. All members helped jointly during the end of the cycle, when the pressure was most intensive.

Finances were arguably the most complex issue of the venture. Before the firm was registered, the family budget and the business funds were practically not separated. This meant that family resources, however scarce, were always there to finance business undertakings (new production cycle, other investments in machinery, etc.), but even more importantly, that business profits were considered as family net income, and used for family consumption. After the firm was registered, the financial logic became even more complex. However, even before the registration of the firm, there were interesting traits related to the distribution of funds. Namely, though the informant's mother was working intensively on the estate (not only on farm related tasks, but also on the maintenance of the house, the regulation of administration-related tasks that demand time consuming trips to Belgrade etc.), was taking care of most of the house-related additional expenses (electricity bills etc.), and was contributing to the budget from her pension, she never directly participated in the share of the profit. The relative also helped intensively, and contributed to the business fund by making available half of the sum of his pension, but he was also not included directly in the profit sharing. In a way, Milutin's nuclear family was being helped both non-financially and financially by his mother and his relative, even though they all lived and worked together under a single roof much like in a traditional extended family or zadruga. In other words, apart from the family business "exploiting" the family (and the other way round), Milutin's nuclear family was additionally "exploiting" other members of the extended family, or more precisely, of the household.

Another peculiarity had to do with the fact that from the moment he resigned from his second job, Milutin remained the only grown-up who did not receive a permanent salary or pension. Following a feminine strategy comparable to the

${ }^{12}$ Here, one might reflect on the advantages of grey zone "amateur entrepreneurial" experiences over unusable professional management skills from a different era.

Етноантрополочки проблеми н.с. год. 1. св. 1 (2006) 
one practised by Milutin's mother ${ }^{13}$, from the moment she found employment his wife generally used her salary to meet the needs of her daughters, and of her parents and relatives in Montenegro, as well as her own needs, and did not contribute directly to the business fund. In other words, she used her salary as a form of exclusive personal-disposition fund principally not integrated into the interconnected family and business funds. As was hinted, after the firm got registered the logic of sharing and consumption changed again. The net income of the business had to be divided among the partners (at first among the three of them, and later between Milutin and S.S., as the third local partner left, while the foreign partner did not want to participate in the small production cycles and was therefore not entitled to a share of the income) according to the percentage of capital invested into the production cycle. As the family was still the main workforce behind the joint business (S.S. was less and less capable of meeting his obligations on the farm due to overlapping with his other business activities), it was therefore directly contributing to the profit of the other partner(s). It was expected that the family work would be reimbursed by positive effects of S.S.'s marketing and distributive skills, and by the part of the transportation costs which he covered himself. However, the extent of family exploitation was at times actually increasing, instead of decreasing. This was particularly true in cases when something went wrong - like when an incurable form of poultry sickness stroke twice in the year 2003. Due to the facts that health-protection remained Milutin's exclusive responsibility, and that the business remained without any insurance, the considerable losses were directly transferred onto the family budget.

In the end, owing to the described chain of bureaucratic and political setbacks, but also to the inherent economic instability of a venture that brought together strictly profit seeking partners and a family production unit tailored for a subsistence production, the plan to set up an organic export-oriented production never fully materialized. Several larger cycles for the domestic market - local butchers and Belgrade restaurants, together with the usual small scale production for auto-consumption and the circle of friends and relatives were the only real results of the joint venture during 2003 and 2004. By the end of

${ }^{13}$ While the informant's mother was indeed contributing to the business fund, she was in fact helping directly her son through financing what she saw as his venture, therefore doing the same thing as his wife, who was spending her funds mostly on her daughters and relatives. The anthropologist Andrei Simić proposed a seductive culturalist explanation of such behavior: "The power of this maternal image is rooted in moral superiority derived from self-abnegation and suffering phrased in a mother's devotion to the well-being of her children at the expense of other forms of self-realization. In this way, 'maternal sacrifice' provides the keystone for the support of a structure of guilt on the part of children, especially sons, assuring the perpetuation of a mother's influence and power throughout her lifetime." See Simić 1999 : 26.

Етноантрополошки проблеми н.с. год. 1. св. 1 (2006) 
2004 both local partners had already left the business, one to fully return to taxiing and jobs in the grey zone, the other to work as a high tech precision mechanic for a medical equipment maintenance firm in Switzerland. The German partner then opted to withdraw from Serbia for the time being.

In the beginning of 2005, Milutin finally felt that he had enough of it all he decided to abandon both his subsistence production and his more ambitious entrepreneurial adventures, and to return to his true vocation of salaried manager. Instead of a state-owned firm, this time he put his trust in a medium size, rapidly expanding private firm in the agro-veterinary and fodder businesses. Like a hooked fish thrown back into the water, he spent the first half of the year tirelessly renewing his professional contacts abandoned more than a decade ago, while simultaneously scheming how to conquer the small but rapidly growing local market for cattle and poultry food additives and medicaments. However, even as he was regaining his old reflexes, Milutin insisted that he would never stop eying up opportunities to make true the dream of establishing a large-scale organic poultry production.

\section{Instead of a conclusion, or can reasonable generalisations be drawn from a case as particular as the one presented?}

What has emerged up to now is a picture full of contradictions. A successful manager was pushed into becoming a self-employed agricultural producer, struggling hard with economic ups and downs for more than a decade, but then decided to take his risks and reinvent himself as an entrepreneur. In the end, after learning the hard way that his professional skills were hardly what was expected from a successful transitional entrepreneur, he switched back to what he was best at - to being a manager in a well organized firm that can supply him with the logistics that he obviously depends on for doing his work successfully. Under socialism he was initiated into the privileged but politically marginalised managerial "caste" (the "technocrats"), but almost simultaneously became acculturated to the ways of Western capitalism to such a degree that he actually thought that he could outdo his counterparts in their own game. In the next period, his venture oscillated between a peasant subsistence economy and a registered international joint venture. He calculated possible profits on international markets, while selling meat and eggs to neighbours and kinsmen. He was laying bricks with his own hands while arranging for the introduction of pioneering technologies from the EU. He dreamed of going big, while devising strategies to keep his family fed and clothed.

Can this case, so riddled with contrasts and contradictions, speak of anything else apart from its own complexity and in-between-ness? The answer that is proposed here is yes - the story of Milutin opens up a privileged perspective on

Етноантрополочки проблеми н.с. год. 1. св. 1 (2006) 
a wide set of issues that are important for the understanding of contemporary Serbian socio-economic culture(s), agriculture, and economy in general. Namely, the combination of individual life narratives, professional histories, and in situ observation provides the much needed practical frame for the contextualisation of grand themes like the role of culture, or the logic of political and economic transitions.

First of all, the case study reveals the actual "cultural resources" that the informant was ready to turn to in order to sustain his entrepreneurial efforts:

- $\quad$ The multi-generational extended family structure doubling as a production and consumption unit;

- The readiness of family members and kinsfolk to work intensively for no practical financial remuneration apart from housing, food and clothing, characteristic of a non-monetarised, peasant subsistence type of economy;

- $\quad$ The preserving of special ties linking mothers to their adult, and in particular male offspring, and the propensity for demonstratively self-sacrificial behaviour on behalf of the mothers, coupled with tolerance and mild dependency on the side of the sons, which is complemented by an exaggerated and often theatrical machismo, described together as "cryptomatriarchy" by some authors;

- The instrumentalisation of friendship and neighbourhood ties, that is, the use of existing inherently non-economic relationships for the mutual advancement of economic interests;

- The relative disregard of existing legal and fiscal frames, and of the generalized interests of the state and society as such, and the concentration of primary loyalty on the family, kinship ties, and local networks.

However, this case study also reveals that instances of relying on "cultural resources" should not be automatically taken as evidence decidedly supporting the stance of cultural determinism. Rather, the reliance of small entrepreneurs on such resources in an environment in which they can not rely on state protection, have no significant private wealth, and face a shortage of preferential loans and other means of financial support, should rather be interpreted as instances of rational coping strategies (Kuczi 1997/8 : 51).

Next, what the presented case study argues for is a nuanced approach to the issue of culture as a determining factor. First, Milutin's case seems to downplay the role of a broad and unified cultural pattern, as exemplified by the idea of a "national" or of a regional (Western or Eastern) culture, while putting to the fore the role of other more specific variants, like managerial or entrepreneurial cultures. Namely, Milutin's case demonstrates the relative ease with which "Eastern" professional cultures can be Westernised. On the other hand, Milutin seems to have been marked by his managerial experiences during socialism to such an extent that they hindered his attempt to redefine himself as an entrepreneur. Therefore, Milutin's case seems to suggest that "narrow" professional cultures can be more resilient than "broader" national 
or regional ones. Second, while culture (or, more precisely, its various forms) does play an important part, its role as a factor that determines economic behaviour in this rather specific framework is certainly not crucial. Together with the informant, it is possible to see the chances of economic success in contemporary Serbia as severely restricted by inadequate legal, institutional and policy frames, and even more so by widespread politicking and corruption. In that sense, the whole complex infrastructure of laws, policies, institutions, aberrant practices and bureaucratic restraints emerges as the key determinant of economic success or failure in this rather particular case. In a similar vein, Daniel Chirot recently proposed a remarkable, if somewhat excessively muscular effort at taming the crude culturalist determinism often present in the reflections on Eastern European economies in transition:

Insisting that the differences in levels of economic success between various parts of the post-communist world are related to very deep cultural legacies misses the real reasons for them and also makes them seem more permanent than they really are. We now know that substantial modernisation can take place in three generations, or perhaps even less. Some backward parts of Eastern Europe, such as Romania or Bulgaria, for example, have all the elements in place for rapid modernisation. If Serbia had not been led into a disastrous political adventure by its misguided intellectuals (who genuinely believed in a separate "Serbian" mission) and by the Milosevic government, it would have emerged from communism no more backward than Poland. The differences in degree of modernisation between Romania or Bulgaria, and, say, Hungary or Poland, need not last more than one or two generations. Similarly, all of post-communist Europe has the capacity to substantially catch up to Western European levels well before the end of this new century (Chirot 2002 : 7, italics S.N.).

Chirot's somewhat triumphalist rationalism fits well with Milutin's devaluation of culture as a factor that shapes human behaviour. But is this a clear victory? Evidence supplied by Milutin's own case contradicts this interpretation as well. Namely, the presented case seems to speak both against a strong cultural determinist stance, and against overzealous anti-culturalist rationalism. Milutin is definitely right when he objects to being viewed as a zombie of culture, but that fact doesn't miraculously turn him (and all of us, for that sake) into a consequent Kantian either, even if he (together with Chirot) might wish to see himself as one.

A balanced position on the importance of culture was recently voiced by the late Eric Wolf. Namely, speaking about the position of anthropology "among the powers" as well as among other disciplines, Wolf sketched the key traits of a re-emerging instrumentalist, actor-oriented, contextualist, and reality-observing approach, which according to him offers a viable alternative to stronger versions of culturalism and other "nomothetic abstractions":

Етноантрополочки проблеми н.с. год. 1. св. 1 (2006) 
We are now one of the very few remaining observational sciences. Observation has allowed us to separate norms from behavior and to see the relation between the two as problematic. This makes us professionally suspicious of nomothetic abstractions about what people do, whether these are offered by informants, erected by social scientists, or asserted to be the case for all human beings everywhere. Studying Bakweri or Melpa gave us a lively sense that 'things could always be different', and causes us to beware of well-intended generalising schemes that are not grounded in specified populations in defined circumstances. We are thus more likely to be critics than architects of grand theory. This often assigns to us the unwelcome yet vitally needed role of questioning the certainties of others, both social scientists and policy makers.

We are able, furthermore, to watch how people behave as they use normative elements of their culture in ongoing involvements and transactions. This has led us to rethink culture, to see it not as a fixed stock of material and symbolic forms but as repertoires deployed in social action (italics S.N., Wolf 1999 : 132).

If Wolf is to be trusted, the idea of culture as a repertory of various values, norms and ideas deployable in social action (a resource for, instead of a source of), and the reaffirmation of human potential for agency, taken together orient reflection in a more rewarding direction for the understanding of economic activity, than does the idea of culture as a program that makes human computers work (Hofstede 1997). This case study seems to supply further evidence for Wolf's thesis. Namely, it points to the fact that when the functioning of "socio-economic culture(s)" is properly contextualized, linked to actual periods, processes, and persons, then it has to be seen as neither the only, nor the principal factor that can explain observable behaviour, particularly in rapidly changing political, economic, institutional, and legal settings. In other words, if "culture matters", it is only because in a given period some of the conceptions, norms and values that a specific type of culture sustains can, because of reasons not knowable in advance, conspire with other factors to make certain forms of thinking and behaviour possible or probable, and others less so. How actors understand the context in which they are bound to operate seems to be of crucial importance for a valid explanation of the ways in which they relate to the cultural resources that are available to them, and deploy them in their behaviour. In short, they use culture, but are also "used" by culture, and are furthermore victims of their own inconsistencies and incapacities, and of the whimsicalities of the context in which they operate.

Finally, let us turn to what can be learned about the broader themes of agriculture and economy in general. Here, Milutin's case reveals a number of issues that can have considerable importance for the understanding of the contemporary situation in Serbia:

- $\quad$ The "lost generation" issue, that is, the unused economic potential of the relatively young generations of well educated, "EU-compatible" managerial and entrepreneurial elites professionally socialised during the eighties;

Етноантрополошки проблеми н.с. год. 1. св. 1 (2006) 
- The "alternative arena" issue, or the potential importance of the remaining well educated and experienced professionals, whose careers in the state-owned sector were ruined during the breakdown of Serbian economy, for the development of a new brand of small scale, but possibly very effective farmer-type agriculture or medium scale agro-businesses in Serbia;

- $\quad$ The "vital cultural and social resources" issue, that is, the fact that even educated, experienced and Western-oriented local entrepreneurs have to resort at times to the timely, "traditional" subsistence strategies of family work/exploitation and social networking in the absence of legal, institutional and economic surroundings favourable to the establishment of viable businesses;

"The worse, the better" issue, or the unintended opportunities opened up by agricultural decline and extensification for the potential transformation of Serbian agriculture through the introduction of sustainable and organic types of production that are labour intensive and low costing, while at the same time in position to supply highly valued and exportable products;

The "parallel tracks" issue, or the vital importance of devising new types of agricultural and credit policies that will find ways of aiding, protecting and crediting both the emerging farmer-type agricultural entrepreneurs who will eventually spearhead the production of new goods and introduce new technologies capable of meeting ever more strict standards of European markets, as well as the old, still dominant type of peasant subsistence agriculture that supplies its small surplus production to the market at low prices, thereby protecting the standard of living of impoverished social strata;

- $\quad$ The "hidden treasure" issue, or the domains of agricultural production in Serbia for which there exists a credible interest of Western partners prepared for capital investments;

- $\quad$ The "missing link effect", or the crucial role that prospective entrepreneurs accord to substantial legal, institutional, policy and banking reforms for the creation of a businesses-friendly environment in Serbia;

- $\quad$ The "burden of professional routine" issue, or the unexpected difficulties that well established professionals face when attempting to assume new roles, especially entrepreneurial ones, in a radically changed economic environment;

- Finally, the "overestimated factor" issue, or the need to re-examine the importance of relatively static factors, like national socio economic cultures, in the analysis of complex dynamic processes, like economic transitions and supranational integrations, as well as to redirect attention both to individual potentials as well as to legal and institutional transformations which can create preconditions for actual cultural change.

\section{References}

After the Accession. The Socio-Economic Culture of Eastern Europe in the Enlarged Union: An Asset or a Liability, Research Proposal, Vienna: Institute for Social Sciences (IWF), 2002.

Allcock, John B., 2000. Economic modernisation: the agrarian economy, in: Explaining Yugoslavia, London: Hurst, 100-144.

Етноантрополошки проблеми н.с. год. 1. св. 1 (2006) 
Arandarenko, Mihail, 2000. Ekonomska stvarnost Srbije, in: Mladen Lazić, ed., Račiji hod. Srbija u transformacijskim procesima, Beograd: Filip Višnjić, 335-372.

Babović, Marija and Slobodan Cvejić, 2002. Strategije opstanka domaćinstava Srbije u 2002. godini, Beograd: Centar za proučavanje alternativa

Begović, Boris and Boško Mijatović, Eds., Corruption in Serbia, Belgrade: Center for Liberal-Democratic Studies, n.d.

Bogdanov, Natalija, Agriculture of Serbia - Framework and Actions for Transition, Final Report Related to the task 1.1. of the Work Programme, Belgrade: Policy and Legal Advice Centre (PLAC/SCEPP), November 2002, online address:

http://www.plac-yu.org/DownLoads/1.1.1AgricultureOfSerbia.pdf

Bolčić, Silvano, Entrepreneurial Inclinations and New Entrepreneurs in Serbia in the Early 1990s, International Journal of Sociology, Vol. 27, No. 4, Winter 1997-98 : 3-35.

Bønneland, Mette, et al., 2002.Sustainable Agricultural Policy. Research Report, Copenhagen: NOAH - Friends of the Earth Denmark, October

Chapter III, G. Agriculture, in: Stimulating Growth and Creating the Basis for a Sustainable Supply Response, Federal Republic of Yugoslavia. Breaking with the Past: The Path to Stability and Growth. Volume II: Assistance Priorities and Sectoral Analyses, ERTP Program of the World Bank in partnership with the European Commision, (pdf e-book) : 46-49, online address:

http://www.seerecon.org/FRYugoslavia/ERTP/pdf/ERTP Vol 1.pdf

Chapter 11. Agriculture, in: Federal Republic of Yugoslavia. Breaking with the Past: The Path to Stability and Growth. Volume I: The Economic, Social and Institutional Reform Agenda, ERTP Program of the World Bank in partnership with the European Commision, (pdf e-book) : 237-259, online address:

http://www.seerecon.org/FRYugoslavia/ERTP/pdf/ERTP_Vol_2.pdf

Chevalier, Sophie, 2001.Spheres of Exchange in the Bulgarian Transition, Working Paper No. 24, Halle / Saale: Max Planck Institute for Social Anthropology

Chirot, Daniel, 2002. Returning to Reality. Culture, Modernisation, and Various Eastern Europes, Eurozine, online address: www.eurozine.com .

Hofstede, Geert, 1997. Cultures and Organisations. Software of the Mind, New York: McGraw Hill (first published: London 1991).

Konečni, Martin, ed., 2003. The CAPacity-building manual. A background reading material for the Krakow conference on "EU Accession and Agriculture" and a compilation of basic documents and facts and figures on the Common Agricultural Policy for NGOs from Accession Countries, Brussels: Friends of the Earth Europe, November

Kuczi, Tibor, The Post-Communist Transformation and the Social Resources of Entrepreneurs, International Journal of Sociology, Vol. 27, No. 4, Winter 1997-98: 50-83.

Lazić, Mladen, ed., 1994. Razaranje društva. Jugoslovensko društvo u krizi 90-ih, Beograd: Filip Višnjić

Lazić, Mladen, ed., 2000.Račiji hod. Srbija u transformacijskim procesima, Beograd: Filip Višnjić

Naumović, Slobodan, A pehely súlya, in: „Új barazda", 2000 Irodalmi és társadalmi havi lap 2005 : 19-29.

Nemes, Gustav, 2003/2004. Rural Development and Pre-Accession Preparation in Hungary, Final Policy Paper, CPS International Policy Fellowship Program, CPS/CEU/OSI 
Palairet, Michael, The Economic Consequences of Slobodan Milošević, Europe-Asia Studies, Vol. 53, No. 6, 2001 : 903-919.

Perry, Amanda J., The Relationship Between Legal Systems and Economic Development: Integrating Economic and Cultural Approaches, Journal of Law and Society, Vol. 29, No. 2, June 2002 : 282-307.

Strategija poljoprivrede Srbije, Ministarstvo poljoprivrede, šumarstva i vodoprivrede, Beograd 2004.

Swain, Nigel, 2000.The Rural Transition in Post-Socialist Central Europe and the Balkans, Working Paper No. 9, Max Planck Institute for Social Anthropology, Halle / Saale

Tchalakov, Ivan, 2003/2004. After the End of Transition: Policies for the New Innovative Entrepreneurs in Bulgarian Economy, Final Report - Policy Paper, CPS International Policy Fellowship Program, CPS/CEU/OSI

Trompenaars, F., and Hembden-Turner, C. 1998 [1993]. Riding the Waves of Culture: Understanding Cultural Diversity in Business, London: Nicholas Brealey Publishing

van Brakel, Manus, et al., 2002. Sustainable Production and Consumption. A Global Challenge, Milieudefensie/Friends of the Earth Netherlands, Amsterdam

Verheul, Ingrid, Sander Wennekers, David Audretsch, and Roy Thurik, An Eclectic Theory of Entrepreneurship, Tinbergen Institute Discussion Paper, Rotterdam and Amsterdam, TI 2001- 030/3.

Vladimirov, Z., ed., 2003.Competitiveness of Agricultural Producers and Food Processing Enterprises in Bulgaria, Sofia

Vudvord, Suzan, 1997. Balkanska tragedija. Haos i raspad posle hladnog rata, Beograd: Filip Višnjić (trans. of Woodward, Susan, Balkan Tragedy. Chaos and dissolution after the Cold War)

Wolf, Eric, Anthropology among the Powers, Social Anthropology Vol. 7, No. 2, 1999 : $121-134$.

Zizmond, Egon, The Collapse of the Yugoslav Economy, Soviet Studies, Vol. 44, Issue 1, 1992: 101-113.

Слободан Наумовић

О тежини перја, или какве везе има култура са неуспехом да се успостави једна органска линија производње пилетине и ћуретине у савременој Србији?

Ова студија случаја полази од претпоставке да анализе животних и професионалних историја, употпуњене, па и исправљене посматрањем стварног понашања, могу да допринесу свестранијем сагледавању начина на који обухватне категорије као "социо-економске културе" заиста делају у локалним и националним оквирима. Текст је организован у неколико целина које укрштају хронолошки са тематским приступом: Добри стари дани, или о пословању током почетка краја; Менаџер постаје сељак, или о последицама економије деструкције у Србији; Колико је одржив пројекат одрживе пољопривредне производње у реформистичкој Србији; Тајне (неких) транзиционих предузетника, или о органи-

Етноантрополошки проблеми н.с. год. 1. св. 1 (2006) 
зацији породичног посла; Уместо закључка, или могу ли се неки општи закључци извести из једног толико посебног случаја? Рад је заснован на дубинским интервјуима са некадашњим водећим менаџером из агро-ветеринарског сектора једног од највећег српског извозно-увозног предузећа. Осим што разјашњава разлоге због којих је напустио посао и решио да се огледа као самостални пољопривредни произвођач, а затим и да покуша да успостави сопствену органску производњу пилетине и ћуретине, информант у интервјуима нуди и лично виђење политичких, културних и других фактора који су условили растакање југословенске и српске економије, и објашњава стратегије преживљавања које је морао да развије да би одржао своју породицу и производњу. У том смислу, кроз личну причу преламају се неки од најзначајнијих економских, политичких и друштвених процеса који су обележили осамдесете и деведесете године 20. века. Укрштање интервјуа са посматрањем стварног функционисања породичне производње омогућило је да се уоче и одређене дискрепанце између вредности и ставова изнетих у разговорима и описаних и посматраних облика понашања, посебно када се ради о условима непотпуне или чак заустављене транзиције у Србији, диригованог државног капитализма, урушеног правног система, растуће корупције, рата и санкција. Такве дискрепанце отварају питања утемељености истраживања социо-економских култура заснованих искључиво на проучавању ставова и вредности. Ова студија случаја указује и на конкретне културне форме којима је информант прибегавао у оквиру својих стратегија преживљавања, на првом месту вишегенерацијску проширену породицу која истовремено функционише и као потрошачка и као производна јединица; спремност чланова породице и сродника да уложе свој лични рад без икакве надокнаде, карактеристичан за немонетаризовану економију и аутоконзумну производњу; инструментализацију суседских и пријатељских мрежа за остваривање материјалних интереса; спремност на демонстративно пожртвовање мајки у покушају да помогну својој породици, а посебно синовима и слично. Најзад, студија показује да у разматрању утицаја који културе могу имати у сфери економије треба поћи не само од претпоставке о некој конкретној култури као "програму" који омогућава да "људски компјутери" скоро аутоматски функционишу, већ је можда треба схватити и као скуп вредности, норми, идеја и образаца понашања који су употребљиви у конкретним друштвеним ситуацијама, дакле као свесно изабрано средство за нешто, уместо као механички узрок нечега.

Slobodan Naumović

Du poids des plumes, ou qu'est-ce que la culture a à voir avec l'impossibilité d'ouvrir une ligne de production organique de poulet et de dinde en Serbie moderne?

Cette étude d'un cas part du présupposé que l'analyse de l'histoire d'une vie et d'un parcours professionnel, complétée, voire corrigée par l'observation des comportements réels, peut contribuer à envisager d'une manière plus approfondie les véritables modes de

Етноантрополошки проблеми н.с. год. 1. св. 1 (2006) 
fonctionnement des catégories globalisantes - celle, par exemple, des "cultures socioéconomiques" - dans un cadre local et national donné. Le texte est organisé en plusieurs chapitres en fonction des critères chronologique et thématique. L'étude est basée sur des entretiens approfondis avec un ancien gérant de haut niveau, chargé de la filière agrovétérinaire dans une des plus grandes sociétés d'importation et d'exportation en Serbie. L'informateur explique les raisons pour lesquelles il a démissionné de ce poste et, après avoir pris la décision d'exercer la profession d'agriculteur individuel, essayé d'établir sa propre ligne de production organique de poulet et de dinde. En outre, il présente son point de vue personnel sur des facteurs politiques, culturels et autres qui ont abouti à la dégradation des économies yougoslave et serbe, décrivant les stratégies qu'il a dû élaborer pour assurer la survie de sa famille et de son entreprise. Dans ce sens, son histoire personnelle reflète des processus économiques, politiques et sociaux qui ont marqué de façon décisive les années 1980 et 1990. La technique d'entretien, combinée avec l'observation du véritable fonctionnement de l'entreprise familiale, a permis de relever un certain nombre de divergences entre les valeurs et les positions défendues par l'informateur lors de l'entretien, et les formes de comportements observées et décrites; ceci est particulièrement valable pour des questions relatives à la transition inachevée, voire bloquée, en Serbie, au capitalisme d'Etat dirigé, au système légal délabré, à la corruption grandissante, à la guerre et l'embargo. Ces divergences remettent en question le bien-fondé des recherches sur des cultures socio-économiques qui seraient basées exclusivement sur l'étude des positions et des valeurs. Par ailleurs, cette étude d'un cas renvoie aux formes culturelles spécifiques adoptées par l'informateur dans le cadre de ses stratégies de survie. Parmi ces formes culturelles, on relève notamment: une famille élargie plurigénérationnelle, qui fonctionne à la fois comme une unité de consommation et une unité de production; la volonté des membres de la famille et des parents de s'engager personnellement dans l'entreprise sans recevoir de rémunération, ce qui représente une caractéristique de l'économie non monétaire et de la production auto consommatrice; une instrumentalisation des réseaux de voisinage et d'amitié en vue de générer des bénéfices d'ordre matériel; la volonté de la mère de se sacrifier ostensiblement pour aider sa famille et, plus particulièrement, ses fils etc. Cette étude démontre, enfin, que la réflexion sur l'influence exercée par la culture dans le domaine de l'économie ne doit pas être basée uniquement sur le présupposé qu'une culture donnée représente un "logiciel" permettant aux "ordinateurs humains" de fonctionner d'une manière quasi automatique; plutôt, il faudrait l'envisager comme un ensemble de valeurs, normes, idées et modèles de comportement susceptibles d'être mis en oeuvre dans des situations sociales données. En d'autres mots, la culture devrait être considérée, non pas comme une cause mécanique, mais comme un outil choisi délibérément.

Етноантрополошки проблеми н.с. год. 1. св. 1 (2006) 